\title{
Development of Microcontroller-Based Free Fall Motion Learning Materials to Increase Students' Conceptual Understanding
}

\author{
Infianto Boimau ${ }^{1}$, Ruth N. K. Mellu ${ }^{2}$ \\ Physics Education Study Program, STKIP SoE, Nusa Tenggara Timur, Indonesia \\ stafinfiantoboimau@ @stkipsoe.ac.id ${ }^{1}$, stafruthmellu@ stkipsoe.ac.id $^{2}$
}

Received: January $30^{\text {th }}, 2019$. Revised: March $14^{\text {th }}, 2019$. Accepted: March $15^{\text {th }}, 2019$

\section{Keywords :}

Learning Materials;

Conceptual Understanding;

Microcontroller

\begin{abstract}
Students' shortcoming in understanding various concepts of physics is often due to the lack of teaching media can promote student active participation in the learning process. This study aims to develop a valid and effective microcontroller-based physics learning materials as teaching media in enhancing conceptual understanding of free fall motion lessons. This learning materials is developed using the research and development $(R \& D)$ method. Effectiveness test of learning materials using preexperimental research design one group pretest-posttest involve students of physics education program in STKIP SoE. Data collection techniques were done through validation sheets, observations, test questions, and questionnaire sheets. Validation of learning materials through expert testing shows that learning materials are in a valid category. The results of the study shows that learning materials have a positive effect in improving students' conceptual understanding. The effectiveness of the use of learning materials in improving students' understanding of concepts has been analyzed through the results of $\mathrm{N}$-gain calculations which show a moderate score increase. Moreover, the practicality test of learning materials using a Likert scale shows that learning materials are very practical to utilize as teaching media.
\end{abstract}

\section{INTRODUCTION}

Learning achievement of students is often associated with learning problems in understanding lessons. This problem is probable due to ineffective learning on the learner's part, some students even do not feel motivated in participating in class activities. The teaching and learning process often confronts concepts that are abstract and foreign to the daily experience of students, thus lessons becomes difficult to teach for teachers and challenging for students to understand. Visualization is one way and the media can be developed to concretize something abstract. Media is a component of communication, namely as a messenger from the communicator to the communicant. Learning process is a communication process that requires media to improve the quality of learning outcomes [1]. 
One of the applicable teaching media in learning process is learning materials, because learning materials are effective media to communicate abstract concepts and draw students' interest in learning. This was revealed by Sudjana who stated that learning materials are teaching media which contain and carry the characteristics of the concepts learned [2]. Learning materials are a means of communication and interaction between teachers and students in the learning process [3]. According to Iswaji, learning materials are a set of concrete objects designed, created, or arranged intentionally that are used to help embed or develop concepts or principles in learning [4]. Learning materials are used as a medium to convey messages to stimulate thoughts, feelings, attention, and interests of students in the learning process [5].

The application of learning materials allows students to gain knowledge and develop psychomotor skills as well as foster creativity to solve problems at hand. Thus, a quality learning process is generated [2]. Learning materials as teaching media need to be feasible so that benefits of using learning materials in the learning process can be achieved. According to Afriyanto, suitable to use as teaching media have the following characteristics: (1) Learning materials must be in accordance with the concept of physics, (2) Learning materials must be in accordance with the curriculum, (3) the shape and performance of learning materials must be attractive and compatible with the subject (students), (4) learning materials are easy to read and understand for students, and (5) learning materials should be easy to use [6].

Props are learning media with essential role in learning process of physics lessons. The use of props in learning activities overcomes abstractness of physic concepts that are normally quite challenging to grasp, it also aids in scientific work flow and improves general attitudes of students [7]. Props may be used as effective media to boost quality of learning process [8], increase conceptual understanding of physics [9], develop critical thinking ability [10], better academic achievements [11], increase interest in learning [12], as well as improve innovativeness and creativity of learners [13]. Many studies have been undertaken to develop physics learning aids that can be utilized during learning process to enhance conceptual understanding and result of study, such as DC-Series Parallel for Ohm's Law [14], Archimedes' pulley props [15], as well as hydraulic pump props as well as Boyle's balloon [16].

The advancement of science and technology produces various electronic devices that help in developing learning materials; important components in the development of this learning aid including microcontrollers, sensors, Liquid Crystal Display (LCD), and actuators [17]. With these various electronic devices, learning materials developed are more effective, efficient, with better measurement results and visualization. The learning materials produced also cause students to have better interest in learning as well as enhance their creativity and innovativeness [18]. Some microcontroller/ arduino based physics props have been developed as learning media, such as viscometer [19], DC ammeter [20], strain gauge [21], conductivity measuring instrument [22], teslameter [23], fluid velocity measuring devices [24], optical power measuring devices [25], free falls props [26], Malus's law experiment devices [27], physical pendulum experiment devices [28], damped harmonic osilator investigation devices [29][30], RC circuit investigation devices [31][32], and simple harmonic motion investigation devices [33].

Preliminary studies conducted on the learning process shows that students in general are still experiencing misconceptions in cases of free falling objects. Students still have an understanding that objects with larger masses will touch the ground earlier compared to an object with smaller mass. This was also expressed by Ekasari, et al that in an investigation regarding students' concepts of in free fall motion. The study reveals that as much as $80 \%$ of students said that objects with a greater mass will fall / touch the ground first. Such misconception arises due to the lack of innovative interactive media in facilitating students to understand the phenomenon of free fall motion [34]. This research aims to develop a microcontroller-based free falling motion learning materials that are accurate and rigorous, valid, effective, and practical as a teaching media in improving students' conceptual understanding. 


\section{METHOD}

This study uses the research and development $(R \& D)$ method in the field of education to develop free fall motion learning materials. Testing of the products utilize the pre-experimental method with the design of one group pretest-posttest. This research is a development research because it focuses on the development of learning materials that can be applied in the learning process to improve students' conceptual understanding. The products developed in this study are (1) free fall motion aids, (2) learning modules, (3) Student Worksheets, and (4) practical guides.

The subjects of this study are students of STKIP SoE's physics education study program of 2016/2017 school. The sampling technique uses saturated sampling technique due to population limitations. The development of learning materials is carried out in the STKIP SoE's science laboratory, whereas test of effectiveness of the products is carried out in the campus. Data collection techniques of this research include observation techniques, tests, and questionnaires with research instruments in the form of observation sheets, validation sheets, test questions, and questionnaire response sheets.

The stages in research and development are adapted from the research and development model of Borg and Gall which include: (1) potential and problems, (2) data collection, (3) product development, (4) design validation, (5) design revisions, (6) product trials, (7) product revisions, (8) usage trials, (9) product revisions, and (10) implementation and dissemination [35]. In this research, adaptation of the steps above is in accordance with the needs so that three stages are obtained, namely: (1) preliminary study which includes needs analysis, and identification of product resources and specifications, (2) product development which includes learning materials design, learning modules, student worksheets, practical guides, learning compendium, and testing instruments, and (3) product testing and implementation stages which include product validation, internal testing, field testing, product revisions, and final products.

The internal validation phase is carried out to validate the products developed along with evaluation instruments. This internal validation is carried out by experts through both validation and discussion sheets. The validation sheet is developed using a Likert scale and the results of the validation are analyzed using a comparison of the average score against the ideal score to determine the validity of the product. Additionally, the test questions will be tested for validity, reliability, level of difficulty and differentiation before being used as a test instrument. The validity of the test questions is analyzed using the product moment correlation formula, while the reliability test is analyzed using the Cronbach Alpha formula. These test questions are tested on 3rd and 5th semester students.

External testing is a field trial so that it is applied to large scale samples. This trial uses preexperimental research design with the design of one group pretest-posttest. The design of this research model is shown in Table 1. The effect application of learning materials application in the learning process to improve understanding of concepts is measured by the difference in posttest $(\mathrm{O} 2)$ and pretest $(\mathrm{O} 1)$ values, while an increase in understanding of concepts is measured by comparison of posttest $(\mathrm{O} 2)$ and pretest $(\mathrm{O} 1)$ results [35]. To investigate the practicality of the product, the test is done through a questionnaire given to respondents to be filled after the learning process ends. After all products have been tested, then revisions are made to improve product quality based on analysis of learning outcomes and suggestions from validators.

Table 1. Experimental Design For External Test

\begin{tabular}{ccc}
\hline Pretest & Treatment & Posttest \\
\hline $\mathrm{O}_{1}$ & $\mathrm{X}$ & $\mathrm{O}_{2}$ \\
\hline
\end{tabular}

To the effect of learning materials application in improving conceptual understanding is determined based on statistical tests using paired sample t-test (sample related). This test compares the test results before and after the treatment is given. The t-test was determined based on the prerequisite test, namely the normality test using the Chi Squared formula [35]. On the other hand, effectiveness of 
learning materials application in improving students' understanding of concepts is determined based on the normalized gain scores, $\mathrm{N}$-gain. According to Hake, high and low $\mathrm{N}$-gain can be classified as follows: (1) if N-gain is > 70\%, then it falls within the high category; (2) if $\mathrm{N}$-gain is $\leq 30 \%$ and $\leq$ $70 \%$, then it is within the medium category; (3) if N-gain is $<30 \%$, then it fits in the low category [36]. In this study, the data analysis of learning materials practicality employs the Likert scale test.

\section{RESULTS AND DISCUSSIONS}

The application of learning materials in the learning process is capable to reduce the difficulties facing the students in understanding abstract concepts and assisting teachers so that the delivery of concepts becomes more meaningful and can improve students' understanding of the concepts learned. The development of microcontroller-based free fall learning materials produced a prototype as shown in Figure 1. The design of the learning materials consists of two parts, namely the design of the hardware and the design of the software. The hardware consists of a microcontroller circuit, infrared sensor, LCD, push button, actuator, power source, and learning materials mechanical system, while the software uses $\mathrm{C}++$ programming language.

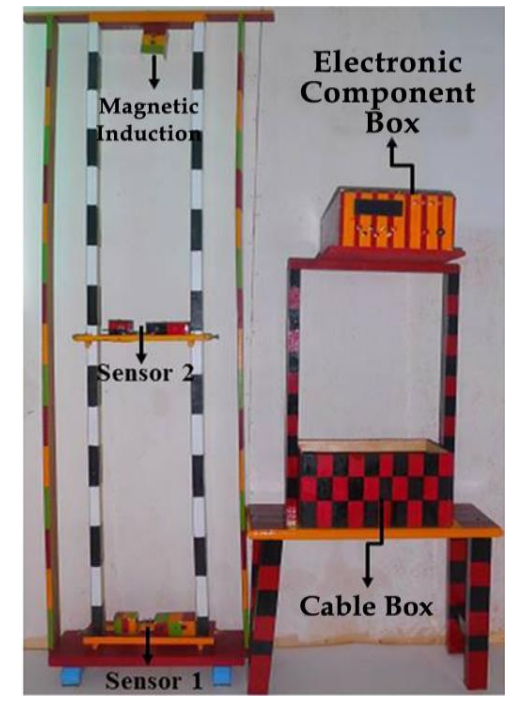

Fig 1. Results of Learning Materials Design

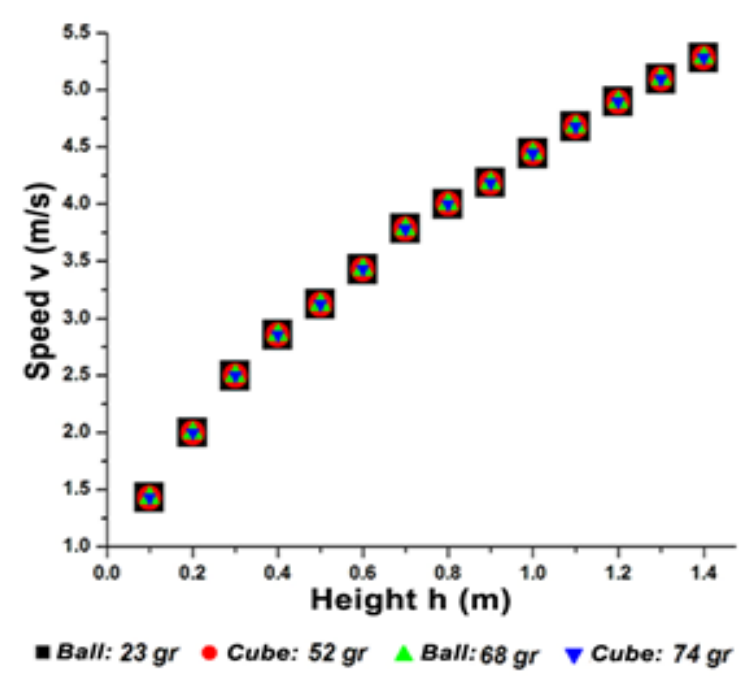

Fig 2. Result of Learning Materials Test 
The microcontroller serves as the main controller in learning materials to regulate the work of electronic devices and measure time with a microcontroller internal timer. The infrared sensor is used as a detector to detect ball motion, LCD as a time measurement viewer, push button as an input button to give input to the microcontroller, actuator as a circuit to control the magnetic field on the iron rod, and the power supply as a current and voltage supply for electronic circuits. Test results of the accuracy and precision of the free falling motion learning materials is shown in Figure 2.

Testing the accuracy and precision of the learning materials is prepared using four of different shapes and masses. Shapes of the objects are solid balls and cubes. This test aims to prove the concept that objects falling freely from the same height will touch the surface of the field at the same time and at the same speed, even though the shape and mass of objects are different. The measurement results shown in Figure 2 show that objects falling freely from a certain height, even though their shape and mass are different, make contact with the surface of the field at the same speed. Such identical speed is because the time taken by objects to reach the surface of the plane is also the similar.

The learning materials are also equipped with learning modules, student worksheets, practical guides, and a learning compendium. These products discuss free fall motion lesson and mechanical energy analysis in the event of free fall motion. These products have also been validated and the validation results are shown in Table 2. This validation is an internal validation carried out by experts. The validation results show that the average product percentage is $87.2 \%$ (valid category) which means that the products developed are suitable for use in the learning process.

Table 2. Validation of Learning Materials and Auxiliary Products of Learning Materials

\begin{tabular}{cccccc}
\hline & \multicolumn{3}{c}{ Validator } & & Percentage \\
\cline { 2 - 4 } Product Name & $\mathbf{1}$ & $\mathbf{2}$ & $\mathbf{3}$ & & $(\mathbf{\%})$ \\
\hline$\quad$ Learning Aid & 3.8 & 3.8 & 3.0 & 3.5 & 87.5 \\
Learning Module: & & & & & \\
$\quad$ Free Fall Motion & 3.8 & 3.4 & 3.0 & 3.4 & 85.0 \\
Mechanical Energy & 3.8 & 4.0 & 3.0 & 3.6 & 90.0 \\
Student Worksheets: & & & & & \\
$\quad$ Free Fall Motion & 3.6 & 3.8 & 3.0 & 3.5 & 87.5 \\
$\quad$ Mechanical Energy & 3.5 & 3.9 & 3.0 & 3.5 & 87.5 \\
$\quad$ Practical Guide & 4.0 & 3.8 & 3.0 & 3.6 & 90.0 \\
Learning Compendium: & & & & & \\
$\quad$ Free Fall Motion & 3.3 & 4.0 & 3.0 & 3.4 & 85.0 \\
Mechanical Energy & 3.3 & 4.0 & 3.0 & 3.4 & 85.0 \\
\hline$\quad$ Average Score & 3.6 & 3.8 & 3.0 & 3.5 & 87.5 \\
\hline
\end{tabular}

Product trials are conducted in small classes consisting of 5 students in third and fifth semester. From the results of the trial, there is a significant increase in the understanding of the concept of free fall motion. Based on the results of the $\mathrm{N}$-gain test analysis, the average increase is 0.6 (medium category). These results indicate that learning with the help of learning materials is effective in improving conceptual understanding. The practicality test obtained an average percentage of $91.5 \%$. This shows that the developed learning materials are very practical to use in the learning process.

Usage trials or field trials have been conducted on a sample of 16 students of the first semester. Field trials are analyzed using one sample t-test. This test is to determine the effect of the application of learning materials developed on understanding concepts. The t-test is also carried out after the requirements are met, namely the data used is normally distributed. From the test results obtained $t_{\text {obtained }}>t_{\text {critical }}$ at the significance level of $5 \%$. Based on the results of this test, Ho is rejected and Ha is accepted, namely there is an increase in understanding the concept by applying free fall motion aids in the learning process. 
Improved understanding of concepts can be analyzed from the results of the pretest and posttest. The results of the conceptual understanding test at the pretest and posttest stages can be seen in comparison based on the lowest, highest, and average values obtained as shown in Figure 3. This graph shows that there is an increase in the lowest value, highest value, average value, and value $\mathrm{N}$-gain after applying learning materials in the learning process. The lowest change in value achieved by students is not significant. These results are influenced by the students' initial knowledge that is still inferior which results in the application of learning materials being insufficient to assist in improving conceptual understanding, especially on indicators interpreting, referencing, summarizing, and explaining. The highest value and average value experienced a significant increase and it is due to students' ability to construct new knowledge and correct misconceptions about the concept of free fall motion.

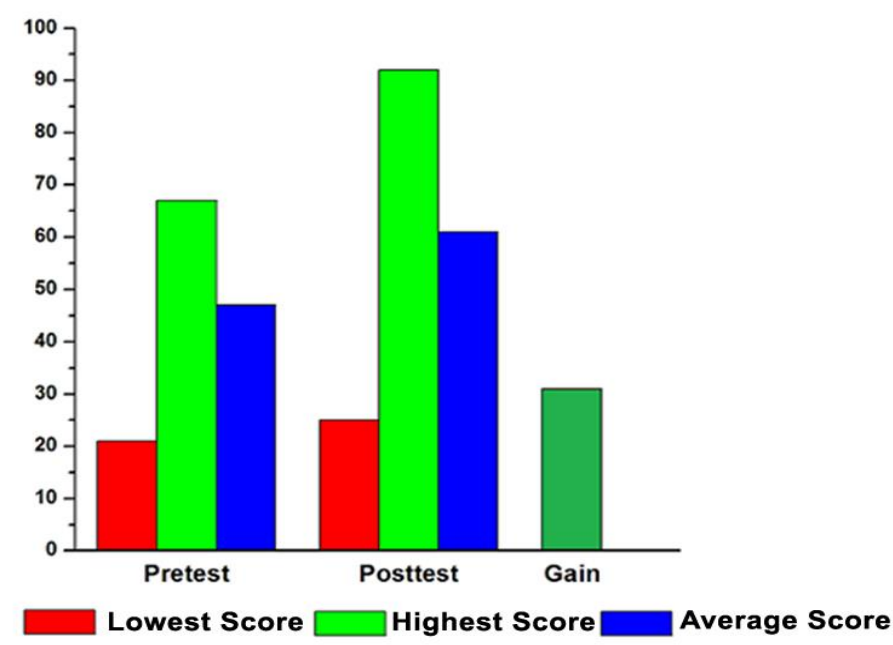

Fig 3. Conceptual Understanding Test Results in Field Trials (Large-scale Trials)

It is possible to enhance the cognitive aspects of conceptual understanding in the $\mathrm{N}$-gain test because students are given the opportunity to experience and explore their own knowledge through experiments using learning materials. This opinion is in line with research results conducted by Erintina who prove that the application of learning materials in the learning process can improve cognitive learning outcomes and increase students' enthusiasm and interest [37]. Similar research result are also obtained by Prasetyarini, et al, which shows that the application of learning materials in the learning process can improve students' understanding of concepts [38].

When percentage results of the pretest and posttest are grouped in the low, medium, and high categories, they can show certain increase in conceptual understanding after the learning using learning materials, as shown in Figure 4. Percentage results of mediocre conceptual understanding have shown a decline, which indicate that there is a decrease in the number of ignorant and misinformed after the application of learning materials for classroom learning. This reduction in percentage is a positive influence of the application of learning materials because students are able to construct their own understanding. Besides, abstractness of the concept does not become an obstacle to understanding physics phenomena, especially for students who prefer visual learning style, because the application of such teaching media makes it easier to grasp the concept in their own way [39]. According to Daryanto, learning styles influence students in the receiving and storing of information about what is learned, consequently there is a need for appropriate media so that it is easier and faster for students to understand lessons [1].

In Figure 4, it is visible that the percentage of understanding concepts within the medium and high categories has increased. Such increase occurs because the application of learning materials helps students to better understand and deepen their knowledge of free fall motion. The learning materials 
applied in the learning process become effective media to improve students' understanding of concepts and cognitive learning outcomes. The results of this analysis are supported by research by Muhaimin, et al which shows that the application of learning materials in the learning process increases students' understanding of concepts and scientific attitudes [40]. The results of a similar study are also obtained by Sumbadi \& Mosik who find that the application of learning materials in the learning process can improve students' cognitive learning outcomes [41].

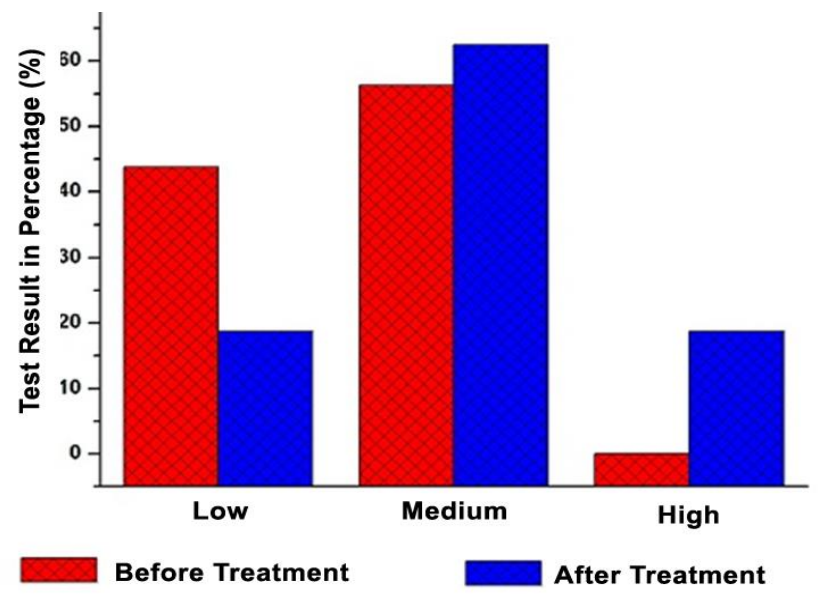

Fig 4. Percentage of Test Results for Understanding Concepts

The effectiveness of free fall motion aids in improving conceptual understanding can also be analyzed from the $\mathrm{N}$-gain test. The results of the $\mathrm{N}$-gain test analysis of each conceptual understanding indicator are shown in Table 3. From the results of the $\mathrm{N}$-gain test analysis it is discernable that indicators for interpretation, comparison, and exemplification shows an increase in the medium category. The increase in the low category occurs in the indicators for referencing, summarizing, and explaining. The average $\mathrm{N}$-gain is in the medium category with a percentage of $31 \%$. These results indicate that there is a significant increase in students' conceptual understanding by applying learning materials in the learning process.

The ability of students to make comparisons, that is to determine the relationship between two ideas or objects, shows an increase in the medium category. The increase in this indicator falls in the medium category because the initial knowledge is still low regarding the concept of free fall motion before being taught using learning materials so that the pretest value is low. After learning using learning materials students are able to understand ideas and objects in the phenomenon of free fall therefore they are able to make precise comparisons when objects with different masses and shapes experience free fall from a certain height. The ability to compare ideas or objects can be increased effectively through experiments using learning materials.

Students are also able to correctly explain the physics when different objects are subjects to free fall. Based on the results of observations and analysis, it is found that after the application of learning materials in the learning process, students are able to correctly explain how objects with different masses and shapes are subjected to free fall motion from the same height will touch the surface of the field at the same time and same speed. Similarly, students are able to draw appropriate conclusions regarding observation results and analyses based on data obtained from the measurement results. In the learning process using learning materials, students are given the opportunity to manage and compare ideas or concepts learned with what is observed.

The interpreting indicator enables students to change the form of an object or information to another form of object or information. The ability to exemplify involves students' ability to find examples or illustrations of concepts and principles, while the ability to conclude means that students are able to make logical conclusions from information received. These indicators have increased in the medium 
category. This increase is due to students being able to discover some new knowledge when they are learning using learning materials. Further notable change is especially in their ability to interpret and conclude after analyzing the results of observations. Students' ability to summarize or abstract general themes and main ideas and the ability to explain or model cause and effect in a system are within the low category. The increase in the indicators for conceptual understanding is caused by the application of learning materials that are able to eliminate abstract notion from lessons taught and stimulate students to analyze what is observed in the experiment.

Table 3. Average Score $<\mathrm{g}>$ of Students' Conceptual Understanding

\begin{tabular}{ccccc}
\hline Indicator & Before $\left(\mathbf{O}_{\mathbf{1}}\right)$ & After $\left(\mathbf{O}_{\mathbf{2}}\right)$ & $\langle\mathbf{g}\rangle \mathbf{( \% )}$ & Category \\
\hline Interpret & 25.00 & 56.25 & 42 & Medium \\
Compare & 81.25 & 93.75 & 67 & Medium \\
Exemplify & 66.67 & 85.42 & 56 & Medium \\
Infer & 40.63 & 57.81 & 29 & Low \\
Summarize & 43.75 & 43.75 & 0 & Low \\
Explain & 47.16 & 57.95 & 20 & Low \\
\hline Average & 50.74 & 65.82 & 31 & Medium \\
\hline
\end{tabular}

Student responses to the products that have been developed namely the learning materials, learning modules, student worksheets, and practicum guides, are obtained using questionnaire sheets given after the learning process. Questionnaire consists of four aspects, including student response to learning materials, learning using learning materials in understanding concepts, learning using learning modules, student worksheets, and practicum guides, and interest in learning modules, student worksheets, and practicum guides developed. The results of the analysis of student responses to the products developed are shown in Table 4. Based on the analysis of the average student response to product practicality, it was found that the products developed are very practical to apply in the learning process to improve conceptual understanding. Learning materials and products developed are useful for enhancing conceptual understanding; they are also effective and practical in their application as a medium of physics learning.

Table 4. Percentage of student response regarding practicality of the developed product

\begin{tabular}{ccc}
\hline Students' Response & Positive Percentage (\%) & Category \\
\hline $\begin{array}{c}\text { Student responses to the usefulness and } \\
\text { attractiveness of learning materials developed. }\end{array}$ & 87.8 & Very Practical \\
$\begin{array}{c}\text { Student responses to the use of learning materials } \\
\text { to improve conceptual understanding. }\end{array}$ & 85.6 & Very Practical \\
$\begin{array}{c}\text { Learning using learning modules, student } \\
\text { worksheets, and practicum guides. }\end{array}$ & 86.7 & Very Practical \\
$\begin{array}{c}\text { Language and interest in learning modules, } \\
\text { student worksheets, and practicum guides. }\end{array}$ & 81.3 & Very Practical \\
\hline Average & 85.35 & Very Practical \\
\hline
\end{tabular}

The results of the analysis obtained through student responses to the application of learning materials shows that students become more interested and motivated to develop the concept of free fall motion through the results of observations and measurements made using learning materials which are carried out repeatedly. High student interest and motivation makes it possible to create quality learning processes so that learning achievement also rises. Such learning process enables students to have a correct understanding and memorize what they learn as expressed by Dale: that learning by doing can explicate a concept significantly and therefore students may remember $90 \%$ of what they learn [42]. Similar discovery is also revealed in the results of Indah \& Prabowo's study that the application of learning materials in the learning process motivate students to be more enthusiastic in conducting experiments and also boost interaction and discussion in study groups [43]. This makes it easier for 
students to understand the concepts in lessons which mean that students' learning outcomes also improve.

\section{CONCLUSION AND SUGGESTION}

Based on the findings of this study, it can be concluded that: (1) microcontroller-based free fall motion learning materials have a positive effect or are able to improve the conceptual understanding of physics teacher candidate students in STKIP SoE regarding free fall motion lessons. Other products such as learning modules, student worksheets, practicum guides, and learning compendium that have been developed are valid and appropriate to use in the learning process as a supplementary product for learning materials. (2) Learning materials can to improve conceptual understanding with an average increase of $31 \%$ (medium category) based on the results of the $\mathrm{N}$-gain test on the results of the pretest and posttest. (3) Student responses to learning materials, learning modules, student worksheets, and practical guides used in the learning process are very positive or very practical to use in improving understanding of concepts and can also help students to be more motivated and active to participate in the learning process.

The learning materials that have been developed need to be further tested at other education levels such as high school equivalents and junior high school equivalents. Such undertaking aims to discover the effect of learning materials on improving student learning outcomes and obtain suggestions to improve these learning to achieve maximum and most effective application. The learning materials also need to be further tested to measure their influence on other cognitive abilities of students.

\section{ACKNOWLEDGMENTS}

Researchers would like to extend our gratitude to the Department of Research, Publication and Community Service (LP3M) of the SoE College of Teacher Training and Education which has funded and facilitated this research and publication.

\section{REFERENCES}

[1] Daryanto. (2013). Media Pembelajaran (2 ${ }^{\text {nd }}$ ed.). Yogyakarta: Gava Media.

[2] Sudjana, N. (2011). Dasar-Dasar Proses Belajar Mengajar (2 ${ }^{\text {nd }}$ ed.). Bandung: Sinar Baru Algensindo.

[3] Arsyad, R. (2009). Media Pembelajaran. Jakarta: PT Rajagrafindo Persada.

[4] Iswaji, D. (2003). Pengembangan Media Pembelajaran Matematika di SLTP. Yogyakarya: FMIPA UNY.

[5] Sadiman, A. (2002). Media Pembelajaran dan Proses Belajar Mengajar, Pengertian Pengembangan dan Pemanfaatannya. Jakarta: Raja Grafindo Persada.

[6] Afriyanto, E. (2015). Pengembangan Media Pembelajaran Alat Peraga pada Materi Hukum Biot Savart di SMA Negeri I Prambanan Klaten. JRKPF UAD, 2(1): 20-24.

[7] Kholifudin M. Y., (2013). Pembelajaran Fisika Berbasis Proyek Pembuatan Alat Resonansi Bunyi dari Lampu Neon Bekas Untuk Membentuk Kerja Ilmiah dan Sikap Ilmiah Pada Siswa. Pertemuan Ilmiah XXVII HFI Jateng \& DIY, Solo, Indonesia.

[8] Isnanto, A., Maftukhin., \& Kurniawan, E. S. (2014). Pengaruh Penggunaan Alat Peraga Berbasis Lingkungan (APBL) Pada Materi Dinamika Partikel Terhadap Kemampuan Psikomotorik P1 Peserta Didik Kelas X SMA Negeri 1 Kutowinangun. Radiasi, 4(1): 30-33.

[9] Prasetyarini, A., Fatmaryanti, S. D., \& Akhdinirwanto, R. W. (2013). Pemanfaatan Alat Peraga IPA Untuk Meningkatkan Pemahaman Konsep Fisika Pada Siswa SMP Negeri I Bulupesantren Kebumen Tahun Pelajaran 2012/2013. Radiasi, 2(1): 7-10.

[10] Hartati, B. (2010). Pengembangan Alat Peraga Gaya Gesek Untuk Meningkatkan Keterampilan 
Development of Microcontroller-Based Free Fall Motion Learning Materials... Infianto Boimau, Ruth N. K. Mellu

Berpikir Kritis Siswa SMA. Jurnal Pendidikan Fisika Indonesia, 6(2): 128-132.

[11] Kusdwiutomo, N. (2008). Pengaruh Pembelajaran Fisika Dengan Media Power Point Disertai Animasi dan Modul Dilengkapi Alat Peraga Terhadap Prestasi Belajar Fisika Ditinjau Dari Kreativitas Siswa. (Unpublished Tesis). Program Pasca Sarjana Universitas Sebelas Maret, Surakarta.

[12] Aththibby, A., \& Alarifin, D. (2015). Pengaruh Permainan Dalam Pembelajaran Fisika Terhadap Motivasi Belajar Peserta Didik. JRKPF UAD, 2(2): 38-41.

[13] Erintina, M. D. (2015). Pengaruh Model Pembelajaran Expository Berbantuan Alat Peraga Terhadap Hasil Belajar Fisika Siswa Kelas VIII SMPN 21 Mataram Tahun Pelajaran 2014/2015. Ganec Swara, 9(1): 140-144.

[14] Riyanti, G. A., Sutikno., \& Masturi. (2015). Perenapan Alat Peraga Seri-Paralel DC Untuk Meningkatkan Pemahaman Siswa Pada Materi Hukum Ohm. Prosiding Seminar Nasional Fisika (E-Journal). Jakarta. Program Studi Pendidikan Fisika dan Fisika, Fakultas MIPA, Universitas Negeri Jakarta.

[15] Palupi, I. A. (2015). Upaya Peningkatan Pemahaman Konsep Hukum Archimedes Melalui Alat Peraga 'Katrol Archimedes' di Kelas XI IPA SMAN 3 Salatiga. Prosiding Seminar Nasional Pendidikan Sains, Salatiga, UKSW.

[16] Puspitarini, L. (2015). Pengembangan Alat Peraga Sains Pompa Hidrolik dan Boyle's Balloon Untuk Meningkatkan Pemahaman Konsep Siswa SMAN I Sayung. (Unpublised Skripsi), Jurusan Fisika Fakultas MIPA Universitas Semarang.

[17] Wicaksono, A., \& Rifai, I. (2013). Pembuatan Alat Peraga Pendidikan Fisika Sub Materi Gerak Jatuh Bebas Berbasis Mikrokontroler Arduino UNO. Seminar Nasional Teknologi Terapan. Yogyakarta, Indonesia.

[18] Susilawati., \& Aryanto, D. (2013). Penerapan Alat Praktikum Viskometer Terhadap Pencapaian Kinerja Mahasiswa Calon Guru Fisika. Seminar Nasional $2^{\text {nd }}$ Lontar Physics Forum.

[19] Ramadhan, D., Serevina, V., \& Raihanati. (2016). Perancangan Alat Praktikum Viskometer Metode Bola Jatuh Bebas Berbasis Sensor Efek Hall UGN3503 Sebagai Media Pembelajaran Fisika. Prosiding Seminar Nasional Fisika, Jakarta, Program Studi Pendidikan Fisika dan Fisika, Fakultas MIPA, Universitas Negeri Jakarta.

[20] Wulandari, D. C., \& Wildian. (2014). Rancang Bangun Ammeter DC Tipe Non-Destructive Berbasis Mikrokontroler ATMega8535 Dengan Sensor Efek Hall ACS712. Jurnal Fisika Unand, 3(2): 121-127.

[21] Saputra, H., \& Yusfi, M. (2013). Rancang Bangun Alat Ukur Regangan Menggunakan Sensor Strain Gauge Berbasis Mikrokontroler ATMega8535 Dengan Tampilan LCD. Jurnal Fisika Unand, 3(2): 162-169.

[22] Syaefullah, R., Yuliyanto, G., \& Suryono, (2006). Rancang Bangun Alat Konduktivitas Panas Bahan Dengan Metode Needle Probe Berbasis Mikrokontroler AT89S52. Jurnal Berkala Fisika, 9(1): 37-42.

[23] Premono, P., Soedjarwanto, N., \& Alam, S. (2015). Rancang Bangun Alat Instrumentasi Pengukuran Digital Kuat Medan Magnetik Dengan Menggunakan Mikrokontroler ATMega8535. Jurnal Rekayasa dan Teknologi Elektro (ELECTRICIAN), 9(3): 160-170.

[24] Novianta, M. A. (2010). Alat Ukur Kecepatan Fluida Dengan Efek Doppler Menggunakan Mikrokontroler AT89S51. Jurnal Teknologi, 3(1): 1-9.

[25] Sianipar, R., Hambali, A., \& Sarwoko. (2012). Perancangan dan Implementasi Alat Ukur Daya Optik Berbasis Mikrokontroler AVR ATMega8535 Dengan Tampilan di Komputer. (unpublished Tugas Akhir), Teknik Telekomunikasi, Fakultas Teknik Elektro, Universitas Telkom.

[26] Kause, M. C., \& Boimau, I. (2019). Rancang Bangun Alat Peraga Fisika Berbasis Arduino (Studi Kasus Gerak Jatuh Bebas). Cyclotron, 2(1): 13-19.

[27] Freitas, W. P. S., Cena, C. R., Alves, D. C. B., \& Goncalves, A. M. B. (2018). Arduino-Based Experiment Demonstrating Malus's Law. Phys. Educ. 53.

[28] Dauphin, C., \& Bouquet, F. (2018). Physical Pendulum Experiment Re-investigated with an Accelerometer Sensor. Paper in Physics. 10

[29] de Castro, L. H. M., Lago, B. L., \& Mondaini, F. (2015). Damped Harmonic Osillator with 
Arduino. Journal of Applied Mathematics and Physics, 3: 631-636.

[30] Goncalves, A. M. B., Cena, C. R., \& Bozano, D. F. (2017). Driven Damped Harmonic Oscillator Resonance with an Arduino. Phys. Educ. 52.

[31] Galeriu, C., Letson, C., \& Esper, G. 2015. An Arduino Investigation of the RC Circuit. The Physics Teacher, 53.

[32] Pereira, N. S. A. (2016). Measuring the RC Time Constant with Arduino. Phys. Educ. 51.

[33] Galeriu, C., Edwards, S., \& Esper, G. 2014. An Arduino Investigation of Simple Harmonic Motion. The Physics Teacher, 52.

[34] Ekasari, D., Suyatna, A., \& Sesunan, F. (2013). Pengembangan Alat Gerak Jatuh Bebas Sebagai Media Pembelajaran Konsep Gerak Jatuh Bebas. Jurnal Pembelajaran Fisika, 1(4): 113-123.

[35] Sugiyono. (2011). Metode Penelitian Kuantitatif, Kualitatif, dan R \& D. Bandung: Alfabeta.

[36] Meltzer, D. E. (2002). The Relationship Between Mathematics Preparation and Conceptual Learning Gains in Physics. American Journal of Physics, 70(7).

[37] Erintina, D. M. (2015). Pengaruh Model Pembelajaran Expository Berbantuan Alat Peraga Terhadap Hasil Belajar Fisika Siswa Kelas VIII SMPN 21 Mataram Tahun Pelajaran 2014/2015. Ganec Swara, 9(1): 140-144.

[38] Prasetyarini, A., Fatmaryanti, D. S., \& Akhdinirwanto, W. R. (2013). Pemanfaatan Alat Peraga IPA Untuk Meningkatkan Pemahaman Konsep Fisika Pada Siswa SMP Negeri I Bulupesantren Kebumen Tahun Pelajaran 2012/2013. Radiasi, 2(1): 7-10.

[39] Gunawan, Harjono, A., \& Imran. (2016). Pengaruh Multimedia Interaktif dan Gaya Belajar Terhadap Penguasaan Konsep Kalor Siswa. Jurnal Pendidikan Fisika Indonesia, 12(2): 118125 .

[40] Muhainin, A., Susilawati, \& Soeprianto, H. (2015). Pengembangan Media Kapasitor dan Pengaruhnya Terhadap Pemahaman Konsep dan Sikap Ilmiah Siswa. Jurnal Pendidikan Fisika Indonesia, 11(1): 59-72.

[41] Sumbadi, A., \& Mosik. (2009). Penggunaan Alat Peraga Papan Optik Untuk Meningkatkan Hasil Belajar Pemantulan Cahaya Pada Siswa Kelas VIII. Jurnal Pendidikan Fisika Indonesia, 5(2): 31-36.

[42] Susilana, R., \& Riyana, C. (2007). Media Pembelajaran. Bandung: Wacana Prima.

[43] Indah, S. D., \& Prabowo. (2014). Pengembangan Alat Peraga Sederhana Gerak Parabola Untuk Memotivasi Siswa Pada Pembelajaran Fisika Pokok Bahasan Gerak Parabola. Jurnal Inovasi Pendidikan Fisika, 3(2): 89-94. 